\title{
Low prevalence of gastrointestinal colonization with antimicrobial-resistant bacteria in high risk units in a Canadian tertiary care centre
}

JOHN M EMBIL MD FRCPC, AMIN KABANI MD FRCPC, GEORGE ZHANEL PharmD PhD, LINDSAY E NICOLLE MD FRCPC

JM EMBIL, A KABANI, G ZHANEL, LE NICOLLE. Low prevalence of gastrointestinal colonization with antimicrobialresistant bacteria in high risk units in a Canadian tertiary care centre. Can J Infect Dis 1996;7(5):307-312.

OBJECTIVE: To determine the prevalence of antimicrobial-resistant bacteria among patients receiving care in high risk units in a Canadian tertiary care centre.

DESIGN: Prevalence study over a four-month period in 1995 with rectal swab or freshly passed stool specimen collected from each patient included in study. Standardized record data extraction for selected patient variables was used.

SETTING: Units at high risk for antimicrobial-resistant organisms at the Health Sciences Centre, Winnipeg, including neonatal (NICU), pediatric (PICU), surgical (SICU) and medical intensive care units (MICU), central dialysis unit (CDU), and the in-patient oncology ward (ONC).

PATIENTS: One hundred and fifty-seven patients admitted to the high risk care units for at least $72 \mathrm{~h}$ were screened. Ward distribution was NICU 13 (8.3\%), PICU nine (5.7\%), SICU 24 (15.3\%), MICU $19(12.1 \%)$, CDU 62 (39.5\%) and ONC 30 (19.1\%). Fifty-one of 157 (32.5\%) patients had urinary drainage devices, $108(68.8 \%)$ had invasive vascular devices, and $57(36.3 \%)$ had had a surgical procedure within the month before specimen collection. In the month before sampling, 114 $(72.6 \%)$ had received antimicrobial therapy, including $21(13.3 \%)$ who had received vancomycin, and $81(51.5 \%)$ were receiving antimicrobials, seven (10.8\%) vancomycin, on the day of sampling.

RESULTS: Antimicrobial susceptibilities were performed on 371 bacterial isolates. There were no vancomycin-resistant enterococci or methicillin-resistant Staphylococcus aureus. Eleven (10.8\%) enterococci were resistant to ampicillin, none of which were $\beta$-lactamase producers, $19(18.6 \%)$ and five $(4.9 \%)$ demonstrated high level resistance to gentamicin and streptomycin, respectively. One $(0.7 \%)$ Escherichia coli was resistant to ciprofloxacin and another to gentamicin. Six (20.7\%) Enterobacter cloacae samples were resistant to cefotaxime. One (2.4\%) Klebsiella species was resistant to ciprofloxacin and another to cefotaxime. Two (16.6\%) Citrobacter species were resistant to cefotaxime. One of 11 (9\%) Pseudomonas aeruginosa isolates was resistant to ceftazidime; none were resistant to piperacillin, aminoglycosides, ciprofloxacin or imipenem.

CONCLUSIONS: The prevalence of antimicrobial-resistant organisms colonizing the gastrointestinal tract in patients in these high risk units is low. The reasons for this low prevalence of antimicrobial resistance require further exploration.

Key Words: Antimicrobial resistance, Dialysis unit, Enterococcus species, Intensive care unit, Pseudomonas aeruginosa

Infectious Diseases, Departments of Medicine and Pediatrics, Department of Medical Microbiology and the Faculty of Pharmacy, University of Manitoba, Winnipeg, Manitoba

Correspondence and reprints: Dr LE Nicolle, Infection Control Unit, MS675D-820 Sherbrook Street, Winnipeg, Manitoba R3A 1R9. Telephone 204-787-4655, fax 204-787-4699

Received for publication February 5, 1996. Accepted March 26, 1996 


\title{
Faible prévalence de colonisation gastro-intestinale par des bactéries résistantes aux antibiotiques dans les unités à haut risque de centres de soins tertiaires au Canada
}

\begin{abstract}
OBJECTIF : Déterminer la prévalence des bactéries résistantes aux antibiotiques chez les patients soignés dans des unités à haut risque de centres de soins tertiaires canadiens.

MODÈLE : Étude de prévalence sur une période de quatre mois en 1995 avec prélèvements rectaux ou spécimen de selles fraîchement recueillis chez des patients participant à l'étude. On a utilisé un mode d'extraction des données des dossiers standardisée pour les variables des patients sélectionnés.

CONTEXTE : Unité à haut risque d'infection par des organismes résistants aux antibiotiques au Health Sciences Centre de Winnipeg, y compris unités néonatales, pédiatriques, chirurgicales, soins intensifs, dialyse et oncologie.

PATIENTS : Cent cinquante-sept patients admis dans ces unités à haut risque pendant au moins 72 heures ont subi un dépistage. La distribution par unité était la suivante : néonatal 13 (8,3\%), pédiatrie 9 (5,7\%), chirurgical 24 (15,3\%), soins intensifs médicaux $19(12,1 \%)$, dialyse $62(39,5 \%)$ et oncologie 30 (19,1\%). Cinquante-et-un patients sur 157 $(32,5 \%)$ portaient des appareils pour le drainage de l'urine, $108(68,8 \%)$ avaient des dispositifs vasculaires effractifs et $57(36,3 \%)$ avaient subi une intervention chirurgicale au cours du mois précédant la collecte des spécimens. Au cours du mois précédant la prise d'échantillons, 114 (72,6 \%) avaient reçu un traitement antibiotique, dont 21 (13,3\%) avaient reçu de la vancomycine et $81(51,5 \%)$ recevaient des antibiotiques [sept $(10,8 \%)$ de la vancomycine] le jour du prélèvement.

RÉSULTATS : Des antibiogrammes ont été effectués sur 371 isolats bactériens. Aucun entérocoque vancomycinorésistant ou Staphylococcus aureus méthycillino-résistant n'a été signalé, 11 entérocoques $(8,8 \%)$ se sont révélés résistants à l'ampicilline, aucun ne produisaient de bêta-lactamase. Dix-neuf $(18,6 \%)$ et cinq $(4,9 \%)$ isolate ont manifesté une forte résistance à la gentamycine et à la streptomycine respectivement. Un $(0,7 \%)$ isolat d'Escherichia coli s'est révélé résistant à la ciprofloxacine et un autre à la gentamicine. Six $(20,7 \%)$ échantillons d'Enterobacter cloacae ont été résistants au céfotaxime. Un $(2,4 \%)$ du genre Klebsiella a été résistant à la ciprofloxacine et un autre au céfotaxime. Deux $(16,6 \%)$ Citrobacter ont été résistants au céfotaxime. Un isolat de Pseudomonas aeruginosa sur 11 (9\%) a été résistant au ceftadizime; aucun n’a été résistant à la pipéracilline, aux aminosides, à la ciprofloxacine ou à l'imipénem. CONCLUSION : La prévalence des organismes résistants aux antimicrobiens colonisant le tractus digestif des patients d'unités à haut risque est faible. Les raisons de cette faible prévalence de la résistance aux antimicrobiens méritent que l'on s'y attarde davantage.
\end{abstract}

B acteria have repeatedly become resistant to previously effective antimicrobials through the first 50 years of the antimicrobial era (1). Bacterial antimicrobial resistance limits therapeutic options (2), adversely influences patient care and outcome, and has significant economic consequences (3). Factors promoting the emergence of antimicrobial resistance include selective pressure of antimicrobial use, the organism's capacity to develop and transmit resistance and the ability of resistant organisms to disseminate within a population (4-6).

The emergence of bacterial pathogens for which no effective antimicrobial therapy is available is of significant concern. This is currently the situation with vancomycin-resistant enterococci (VRE). In particular, the evolution of vancomycinresistant, methicillin-resistant Staphylococcus aureus (MRSA) due to horizontal transfer from VRE would be catastrophic (7). In response to the increasing occurrence of VRE, particularly in facilities in the United States, recommendations for routine screening of high risk populations have been proposed (8). These guidelines suggest that facilities with no VRE isolated from patient specimens should undertake periodic studies of gastrointestinal colonization in high risk groups to ensure the organism is not present in their facility. VRE have not been identified, to date, at The Health Sciences Centre, Winnipeg, Manitoba, a tertiary care institution. This prevalence survey of gastrointestinal colonization was undertaken to ensure that occult colonization of high risk patients was not present. The opportunity was also used to determine the prevalence of gastrointestinal colonization with other resistant organisms of potential clinical importance.

\section{PATIENTS AND METHODS}

Patients: The study took place at The Health Sciences Centre, a 900-bed tertiary care referral centre. Patients for screening were identified during a four-month period in high risk units including the neonatal intensive care unit (NICU) (18 beds), pediatric intensive care unit (PICU), surgical intensive care unit (SICU) (10 beds), medical intensive care unit (MICU) (16 beds), leukemia/bone marrow transplant ward (19 beds) (ONC) and the central dialysis unit (35 dialysis stations) (CDU). These units were considered high risk because of the severity of illness of the population, high intensity of antimicrobial use, high use of invasive devices for vascular access and urinary drainage catheters, high frequency of operative procedures and prolonged hospitalization $(8,9)$. All patients admitted to these units were screened if they had been hospitalized for longer than $72 \mathrm{~h}$; CDU patients, however, were largely ambulatory out-patients receiving dialysis three times per week. Patient data were gathered by means of a chart review by one of the authors. Antibiotic utilization data was obtained for inpatient medications only from the actual medication administration record.

Specimens: One specimen was collected from each patient as either a freshly passed stool or a rectal swab (10-14). Rectal swabs were obtained with a sterile cotton tipped swab and immediately placed into Amies transport media (NCS Diagnostics Inc). Stool specimens were placed into a $115 \mathrm{~mL}$ sterile plastic container (Sage Products, Illinois). Both types of specimens were transported immediately to the clinical microbiology laboratory and plated directly onto blood, MacConkey and 
TABLE 1

Characteristics of patient population screened

\begin{tabular}{|c|c|c|c|c|c|c|c|c|c|c|c|c|}
\hline \multirow[b]{2}{*}{ Unit (n) } & \multicolumn{2}{|c|}{ Sex } & \multirow{2}{*}{$\begin{array}{c}\text { Median age } \\
\text { (range) }\end{array}$} & \multirow{2}{*}{$\begin{array}{l}\text { Median stay } \\
\text { days (range)* }\end{array}$} & \multirow{2}{*}{$\begin{array}{l}\text { NG } \\
\text { n (\%) }\end{array}$} & \multirow{2}{*}{$\begin{array}{c}\text { DM } \\
\text { n (\%) }\end{array}$} & \multirow{2}{*}{$\begin{array}{l}\text { VENT } \\
\text { n (\%) }\end{array}$} & \multirow{2}{*}{$\begin{array}{c}\text { GCP } \\
\text { n } \\
(\%)\end{array}$} & \multicolumn{3}{|c|}{ Catheters n (\%) } & \multirow{2}{*}{$\begin{array}{c}\text { OR } \\
\text { n (\%) }\end{array}$} \\
\hline & Male & Female & & & & & & & Urine & Vas & Fist & \\
\hline $\begin{array}{l}\text { PICU } \\
(9)\end{array}$ & 4 & 5 & $\begin{array}{l}6 \text { months } \\
\text { (1 month- } \\
16 \text { years) }\end{array}$ & $\begin{array}{c}17 \\
(11-105)\end{array}$ & $\begin{array}{c}4 \\
(44)\end{array}$ & 0 & $\begin{array}{c}8 \\
(89)\end{array}$ & 0 & $\begin{array}{c}2 \\
(22)\end{array}$ & $\begin{array}{c}4 \\
(44)\end{array}$ & 0 & $\begin{array}{c}4 \\
(44)\end{array}$ \\
\hline $\begin{array}{r}\text { MICU } \\
(19)\end{array}$ & 8 & 11 & $\begin{array}{r}50 \text { years } \\
(18-85)\end{array}$ & $\begin{array}{c}12 \\
(3-60)\end{array}$ & $\begin{array}{r}16 \\
(84)\end{array}$ & $\begin{array}{c}3 \\
(16)\end{array}$ & $\begin{array}{c}19 \\
(100)\end{array}$ & 0 & $\begin{array}{c}19 \\
(100)\end{array}$ & $\begin{array}{c}19 \\
(100)\end{array}$ & 0 & $\begin{array}{c}10 \\
(53)\end{array}$ \\
\hline $\begin{array}{l}\text { CDU } \\
(62)\end{array}$ & 25 & 37 & $\begin{array}{c}60 \text { years } \\
(24-80)\end{array}$ & $\mathrm{N} / \mathrm{A}$ & 0 & $\begin{array}{l}35 \\
(56)\end{array}$ & 0 & 0 & 0 & $\begin{array}{c}27 \\
(44)\end{array}$ & $\begin{array}{r}35 \\
(56)\end{array}$ & $\begin{array}{c}3 \\
(4.8)\end{array}$ \\
\hline
\end{tabular}

*Duration in specific high risk unit until specimens collected. CDU Central dialysis unit; DM Diabetes mellitus; GCP Granulocytopenia with absolute neutrophil count of less than 500; Fist Hemodialysis fistulas; MICU Medical intensive care unit; N/A Not applicable; NG Nasogastric tubes; NICU Neonatal intensive care unit; ONC Leukemia/bone marrow transplant unit; OR Operative procedure within the month before day of sampling; PICU Pediatric intensive care unit; SICU Surgical intensive care unit; Vas Vascular catheter; VENT Endotracheal tube and mechanical ventilation

TABLE 2

Antimicrobial use

\begin{tabular}{lcccc}
\hline & \multicolumn{2}{c}{ Antimicrobial use within month before sampling n (\%) } & \multicolumn{2}{c}{ Antimicrobial use on day of sampling $\mathbf{n}(\%)$} \\
Unit (n) & All antimicrobials & Vancomycin & All antimicrobials & Vancomycin \\
\hline NICU (13) & $13(100)$ & $4(31)$ & $8(62)$ & $4(31)$ \\
PICU (9) & $7(78)$ & $1(11)$ & $3(33)$ & $1(11)$ \\
SICU (24) & $24(100)$ & $3(13)$ & $17(75)$ & $2(8)$ \\
MICU (19) & $19(100)$ & $3(16)$ & $8(13)$ & $4(11)$ \\
CDU (62) & $21(34)$ & $10(16)$ & $26(87)$ & $4(13)$ \\
ONC (30) & $30(100)$ & $4(13)$ & $80(51)$ & $17(11)$ \\
Total (157) & $114(73)$ & $25(16)$ & \\
\hline
\end{tabular}

CDU Central dialysis unit; MICU Medical intensive care unit; NICU Neonatal intensive care unit; ONC Leukemia/bone marrow transplant unit; PICU Pediatric intensive care unit; SICU Surgical intensive care unit

phenylethyl alcohol blood agar plates. Organisms for identification were determined by inspection of plates and sampling of all colonies with unique morphology. These organisms were then identified using standard biochemical techniques (15). Enterococci were identified on the basis of colonial morphology, a negative catalase test and positive pyrrolidonyl arylamidase reaction. Isolates were not speciated, in accordance with current recommendations (7). Antimicrobial susceptibilities were determined for enterococci using an $10 \mu \mathrm{g}$ ampicillin disc (BBL, Maryland), cefinase disc (BBL) and high-level aminoglycoside-resistant quadrant agar (HLAR) plates (PML Microbiologicals). These plates contained four quadrants, one each with vancomycin $(6 \mathrm{ug} / \mathrm{mL})$, gentamicin $(500 \mu \mathrm{g} / \mathrm{mL})$, streptomycin $(2000 \mu \mathrm{g} / \mathrm{mL})$ and a growth control (MuellerHinton agar). Positive and negative controls were included on each plate. All isolates of Gram-positive, coagulase positive cocci were screened for methicillin-resistance by growth on a Mueller-Hinton agar plate containing a $1 \mu \mathrm{g}$ oxacillin disc. Because no potential MRSA were detected, further confirmatory methods were not performed. Up to five colonies per plate of Gram-negative bacilli were isolated and identified, and antimicrobial susceptibilities were determined by Micro Scan dried Gram-negative panel 'neg combo 14' system according to the manufacturers recommendations (Baxter Diagnostics Inc, Illinois). All panels were interpreted using the Auto Scan-4 (Baxter Diagnostics Inc) automated panel reader.

Definitions: The National Committee for Clinical Laboratory Standards were followed for the performance and interpretation of antimicrobial susceptibilities $(16,17)$. Enterococci were considered ampicillin-resistant if the zone of growth inhibition around the ampicillin disc was $17 \mathrm{~mm}$ or less, growth on the gentamicin or streptomycin quadrants of the 
TABLE 3

Distribution of organisms detected on gastrointestinal screening

\begin{tabular}{|c|c|c|}
\hline Organism & Isolates n (\%)* & Patients $\mathbf{n}(\%)^{+}$ \\
\hline Staphylococcus aureus & $6(1.6)$ & $6(4)$ \\
\hline Enterococcus species & $102(28)$ & $85(54)$ \\
\hline Escherichia coli & $151(41)$ & $84(54)$ \\
\hline Enterobacter cloacae & $29(7.8)$ & $22(14)$ \\
\hline Enterobacter aerogenes & $4(1.1)$ & $3(2)$ \\
\hline Klebsiella species & $42(11)$ & $35(22)$ \\
\hline Citrobacter species & $12(3.2)$ & $10(6)$ \\
\hline Pseudomonas aeruginosa & $11(2.9)$ & $10(6)$ \\
\hline Pseudomonas species & $2(0.5)$ & $1(0.6)$ \\
\hline Proteus mirabilis & $7(1.9)$ & $7(4)$ \\
\hline Other Gram-negatives $^{\ddagger}$ & $5(1.3)$ & $5(3)$ \\
\hline Total & 371 & 157 \\
\hline \multicolumn{3}{|c|}{$\begin{array}{l}\left.{ }^{*} \text { Number of isolates (Percentage isolate type }[n / 371 \times 100]\right) ;{ }^{+} \text {Number of } \\
\text { patients with isolates (Percentage of all patients with organism } \\
[n / 157 \times 100]) .{ }^{\ddagger} \text { Hafnei alvia, Morganella morganii, Escherichia vulneris, } \\
\text { Aeromonas hydrophilus }\end{array}$} \\
\hline
\end{tabular}

HLAR plate indicated high level aminoglycoside resistance, and growth on the vancomycin quadrant was indicative of vancomycin resistance. For S aureus, a zone of growth inhibition $13 \mathrm{~mm}$ or less around the oxacillin disc identified methicillin resistance. Enterobacteriaceae were considered resistant if the minimum inhibitory concentrations (MIC) were $8 \mu \mathrm{g} / \mathrm{mL}$ or greater for ampicillin; $16 \mu \mathrm{g} / \mathrm{mL}$ for piperacillin; $8 \mu \mathrm{g} / \mathrm{mL}$ for cefotaxime; $4 \mu \mathrm{g} / \mathrm{mL}$ for gentamicin or tobramycin; $1 \mu \mathrm{g} / \mathrm{mL}$ for ciprofloxacin, $2 / 38 \mu \mathrm{g} / \mathrm{mL}$ for trimethoprim/sulfamethoxazole, and $4 \mu \mathrm{g} / \mathrm{mL}$ for imipenem. Pseudomonas species were considered resistant if the MIC was greater than $64 \mu \mathrm{g} / \mathrm{mL}$ for piperacillin, $8 \mu \mathrm{g} / \mathrm{mL}$ or greater for ceftazidime, greater than $4 \mu \mathrm{g} / \mathrm{mL}$ for gentamicin or tobramycin, and greater than $1 \mu \mathrm{g} / \mathrm{mL}$ for ciprofloxacin.

\section{RESULTS}

Patient characteristics: One hundred and fifty-seven patients were screened. The number of patients in each unit and pertinent demographic characteristics are shown in Table 1. Patients were characterized by a high intensity of invasive procedures and a high use of vascular access devices (Table 1), as well as antimicrobial use (Table 2). One hundred and nine patients had 133 invasive vascular access catheters, broken down as follows: arterial pressure monitors (34;26\%), peripherally inserted central venous catheters and central venous catheters $(66 ; 51 \%)$; umbilical artery and vein catheters $(6 ; 5 \%)$; and hemodialysis catheters $(27 ; 20 \%)$. On the day of screening, $97(61.7 \%)$ patients were receiving antimicrobials; of these 17 $(10.8 \%)$ were receiving intravenous vancomycin. Within the month before sampling, 114 (72.6\%) patients had received antimicrobial therapy, including 25 (15.9\%) who received vancomycin. Of the other antimicrobials used in the month before sampling, 51 (32\%) patients received aminoglycosides, 17
(11\%) received piperacillin, $17(11 \%)$ received third-generation cephalosporins and three $(2 \%)$ received imipenem. No patient had received oral vancomycin therapy. All NICU, SICU, MICU and ONC patients had received broad spectrum antimicrobial therapy within the month before screening. Excluding ambulatory CDU patients, $98 \%$ of all in-patients had received antimicrobials within the month before sampling, and $76 \%$ were receiving them on the day of sampling. Similarly, $26 \%$ had received vancomycin within the month before sampling, and $18 \%$ were receiving them on the day of sampling.

Microorganisms: The distribution of bacterial isolates is shown in Table 3. The largest numbers of isolates were Enterococcus species and Escherichia coli. All S aureus isolates were methicillin-susceptible. The resistance profiles of Enterococcus species are shown in Table 4. No vancomycin-resistant enterococci were identified. Ampicillin and high level gentamicin resistance ( $10.7 \%$ and $18.6 \%$, respectively) were identified in adult units only. High level streptomycin resistance (4.9\%) was observed in both adult and pediatric units. Two isolates (one from CDU and the other from MICU) demonstrated high level resistance to both gentamicin and streptomycin; both were sensitive to ampicillin. The ampicillin-resistant enterococci did not produce $\beta$-lactamase, nor were they resistant to the aminoglycosides.

The prevalence of resistance among Enterobacteriaceae was low for cefotaxime (5.2\%), gentamicin (0.4\%), ciprofloxacin (0.8) and imipenem (0.8\%) (Table 5). About one-half of all isolates were resistant to ampicillin and one-quarter to piperacillin. Only 10 patients $(6.4 \%)$ were colonized with Pseudomonas aeruginosa, none from NICU, one from PICU (11\% of PICU patients), one from CDU (1.6\%), one from ONC $(3.3 \%)$, two from MICU (11\%) and five from SICU (21\%). All $11 \mathrm{P}$ aeruginosa strains isolated were sensitive to piperacillin, aminoglycosides, ciprofloxacin and imipenem. Only one isolate from SICU (9\%) was resistant to ceftazidime.

\section{DISCUSSION}

In this study, only bowel colonization was evaluated. Gastrointestinal colonization serves as a window to the emergence of resistance $(10,11)$, as the commensal flora may ultimately cause infections in patients $(10,12)$. Over the past two decades a number of studies from Europe, South Africa and the United States have described the emergence of antimicrobial resistance in bowel flora. These studies, however, differ methodologically, and direct comparisons with our observations are difficult $(10-14,18)$. We considered patients admitted to critical care areas, while other authors evaluated ambulatory individuals, patients in noncritical care areas and persons not receiving antimicrobials. In addition, many recent studies have considered all nosocomial isolates and not specifically the bowel flora (18). In Canada (19-21), however, the emergence of nosocomial antimicrobial resistance, to date, has not reached the proportions reported in the United States $(5,8,22)$ or overseas (13).

Nosocomial MRSA was not detected in any of the screened patients. The bowel, however, would not generally be a primary reservoir for S aureus (5). For enterococci, the prevalence 
TABLE 4

Antimicrobial resistance profiles of Enterococcus species isolated

\begin{tabular}{|c|c|c|c|c|c|c|}
\hline \multirow[b]{2}{*}{ Unit (n) } & \multirow[b]{2}{*}{ Isolates (n) } & \multirow[b]{2}{*}{ Patient prevalence (\%) } & \multicolumn{4}{|c|}{ Resistance (\%) } \\
\hline & & & AMP & GM & STRP & VA \\
\hline NICU (13) & 4 & $4(31)$ & 0 & 0 & 0 & 0 \\
\hline PICU (9) & 8 & $6(67)$ & 0 & 0 & $1(13)$ & 0 \\
\hline SICU (24) & 19 & $18(75)$ & $1(5.3)$ & $3(16)$ & $1(5.3)$ & 0 \\
\hline MICU (19) & 21 & $17(90)$ & $6(29)$ & $10(48)$ & $1(4.8)$ & 0 \\
\hline CDU (62) & 35 & $29(47)$ & $4(11)$ & $6(17)$ & $2(5.7)$ & 0 \\
\hline ONC (30) & 15 & $11(37)$ & 0 & 0 & 0 & 0 \\
\hline Total (157) & 102 & $85(54)$ & $11(11)$ & 19 (19) & $5(5)$ & 0 \\
\hline
\end{tabular}

AMP Ampicillin; CDU Central dialysis unit; GM High level gentamicin; MICU Medical intensive care unit; NICU Neonatal intensive care unit; ONC Leukemia/bone marrow transplant ward; PICU Pediatric intensive care unit; SICU Surgical intensive care unit; STRP High level streptomycin; VA Vancomycin

TABLE 5

Resistance profiles of Enterobacteriaceae

\begin{tabular}{|c|c|c|c|c|c|c|c|}
\hline \multirow[b]{2}{*}{ Organism (n) } & \multicolumn{7}{|c|}{ Resistance $\mathbf{n}(\%)$} \\
\hline & AMP & PIP & CTX & GM & SXT & CIP & IMP \\
\hline Escherichia coli (151) & $43(29)$ & $44(29)$ & 0 & $1(0.7)$ & $29(19)$ & $1(0.7)$ & 0 \\
\hline Enterobacter cloacae (29) & $19(66)$ & $4(14)$ & $6(21)$ & 0 & $3(10)$ & 0 & 0 \\
\hline Enterobacter aerogenes (4) & $4(100)$ & $4(100)$ & $4(100)$ & 0 & 0 & 0 & 0 \\
\hline Klebsiella species (42) & $37(88)$ & $9(21)$ & $1(2.4)$ & 0 & $1(2.4)$ & $1(2.4)$ & 0 \\
\hline Citrobacter species (12) & $9(75)$ & $3(25)$ & $2(17)$ & 0 & 0 & 0 & 0 \\
\hline Proteus mirabilis (7) & $1(14)$ & 0 & 0 & 0 & $1(14)$ & 0 & $2(29)$ \\
\hline Other Gram-negatives (5)* & $5(100)$ & $4(80)$ & 0 & 0 & 0 & 0 & 0 \\
\hline Total (250) & $118(47)$ & $68(27)$ & $13(5.2)$ & $1(0.4)$ & $34(14)$ & $2(0.8)$ & $2(0.8)$ \\
\hline
\end{tabular}

*Hafnei alvia, Morganella morganii, Escherichia vulneris, Aeromonas hydrophilus. AMP Ampicillin; CIP ciprofloxacin; CTX Cefotaxime; GM Gentamicin; IMP Imipenem; PIP Piperacillin; SXT Trimethoprim/sulfamethoxazole

of ampicillin resistance of $11 \%$ (all non- $B$-lactamase producers), $19 \%$ high level gentamicin resistance and $4.9 \%$ high level streptomycin resistance were also low compared with previous published reports. If only the MICU enterococcal isolates were considered, there was $29 \%$ ampicillin resistance and $48 \%$ high level gentamicin resistance. In the United States, prevalence reports of ampicillin resistance have varied from $9.0 \%$ (23) to $40.0 \%$ (24), and high level resistance to gentamicin or streptomycin for both wound and blood isolates was reported as $38 \%$ (25). No VRE were detected among our nosocomial isolates. Prevalence of VRE is highly variable among institutions, but in at least one New York facility, between $28.6 \%$ and $64 \%$ of patients receiving intravenous vancomycin had VRE detected on rectal swabs (26).

A recent study (19) reported cross-Canada resistance profiles of nosocomial Gram-negative bacteria. This study is not directly comparable with ours because it enrolled all patients, not just those admitted to high risk units, and clinical isolates from all sites, not exclusively gastrointestinal carriage. The Gram-negative isolates in our high risk units, however, showed a prevalence of antimicrobial resistance comparable with or more sensitive than those of the cross-Canada study (19). One Klebsiella species isolate was resistant to cefotaxime; the exact mechanisms of this organism's resistance to cefotaxime were not established. When our observations were compared with those of an American study from 1987 (22), which also included all clinical nosocomial isolates from both a community and a tertiary care centre, our resistance profiles were generally more in keeping with those of an American community hospital in the mid-1980s. The lower prevalence of resistance observed in this study compared with reports from the United States may be for two reasons. Specifically, there may be because of a reporting bias such that hospitals with an increased prevalence of antimicrobial resistance are more likely to report their experience. Alternatively, patients in our institution may have a lower prevalence of resistance than similar patients in other institutions (18).

With increasing broad spectrum antimicrobial use the selective pressure leading to the development of resistance increases $(27,28)$. As antimicrobial resistance occurs, agents once held in reserve become first-line therapies (7). We believe that we have been able to maintain the low prevalence of resistance reported in this study, at least in part, through restrictive antimicrobialuse policies and an effective infection control program. Further studies of other institutions with different patterns of prevalence of resistance may help to clarify the contribution of different factors to prevalence rates. The observations from this study will 
serve as a baseline to be used in ongoing surveillance for the emergence of resistant organisms in our facility.

ACKNOWLEDGEMENTS: The authors thank Brenda Dyck BScN, Judy McLeod RN, Lisa Romance RN, Myra Grabowski ART, unit nursing staff and clinical microbiology. Brenda DesRosiers provided secretarial assistance. Dr Zhanel is supported by a Merck Frosst Chair in Pharmaceutical Microbiology.

\section{REFERENCES}

1. Neu HC. The crisis in antibiotic resistance. Science 1992;257:1064.

2. Swartz MN. Hospital-acquired infections: Diseases with increasingly limited therapies. Proc Natl Acad Sci USA 1994;91:2420-7.

3. Holmberg SD, Solomon SL, Blake PA. Health and economic impacts of antimicrobial resistance. Rev Infect Dis 1987;9:1065-78.

4. Pechere J-C. Antibiotic resistance is selected primarily in our patients. Infect Control Hosp Epidemiol 1994;15:472-7.

5. Tomasz A. Multiple-antibiotic-resistant pathogenic bacteria: A report on the Rockefeller University Workshop. N Engl J Med 1994;330:1247-51.

6. Moreno F, Grota P, Crips C, et al. Clinical and molecular epidemiology of vancomycin-resistant Enterococcus faecium during its emergence in a city in Southern Texas. Clin Infect Dis 1995;21:1234-7.

7. Noble WC, Virani Z, Cree R. Co-transfer of vancomycin and other resistance genes from Enterococcus faecalis NCTC 12201 to Staphylococcus aureus. FEMS Microbiol Lett 1992;93:195-8.

8. Hospital Infection Control Practices Advisory Committee (HICPAC). Special report: Recommendations for preventing the spread of vancomycin resistance. Infect Control Hosp Epidemiol 1995;16:105-13.

9. Cohen ML. Epidemiology of drug resistance: implications for a post-antimicrobial era. Science 1992;257:1050-5.

10. Hawkey PM. Resistant bacteria in the normal human flora. J Antimicrob Chemother 1986;18(Suppl):C133-9.

11. Vollaard EJ, Clasener HAL. Colonization resistance. Antimicrob Agents Chemother 1994;38:409-14.

12. Edmond MB, Ober JF, Weinbaum DL, et al. Vancomycin-resistant Enterococcus faecium bacteremia: Risk factors for infection. Clin Infect Dis 1995;20:1126-33.

13. Shanahan PMA, Wylie BA, Adrian PV, Koornhof HJ, Thomson CJ, Amyes SGB. The prevalence of antimicrobial resistance in human faecal flora in South Africa. Epidemiol Infect 1993;111:221-8.

14. Levy SB, Marshall B, Schluederberg S, Rowse D, Davis J. High frequency of antimicrobial resistance in human fecal flora. Antimicrob Agents Chemother 1988;32:1801-6.

15. Facklam RR, Sahm D. Enterococcus. In: Murray PR, Baron EJ,
Pfaller MA, Tenover FC, Yoken RH, eds. Manual of Clinical Microbiology, 6th edn. Washington: ASM Press, 1995:308-15.

16. National Committee for Clinical Laboratory Procedures. Methods for dilution antimicrobial susceptibility tests for bacteria that grow aerobically, NCCLS Document M7-Aa3, 3rd edn. Villanova: National Committee for Clinical Laboratory Standards, 1993.

17. National Committee for Clinical Laboratory Procedures. Performance standards for antimicrobial disk susceptibility tests, NCCLS Document M2-A5, 5th edn. Villanova: National Committee for Clinical Laboratory Standards, 1993.

18. Morris JG, Shay DK, Hebden JN, et al. Enterococci resistant to multiple antimicrobial agents, including vancomycin. Establishment of endemicity in a university medical centre. Ann Intern Med 1995;123:250-9.

19. Scriver SR, Canadian Antimicrobial Resistance Study Group, Low DE. Comparative activity of several antimicrobial agents against nosocomial Gram-negative rods isolated across Canada. Can J Infect Dis 1995;6:76-82.

20. Embil J, Ramotar K, Romance L, et al. Methicillin-resistant Staphylococcus aureus in tertiary care institutions on the Canadian prairies 1990-1992. Infect Control Hosp Epidemiol 1994;15:646-51.

21. Gold WL, Ng J, Goldman H, et al. The epidemiology of methicillin-resistant Staphylococcus aureus in acute care facilities (ACFs): It may not be too late. Clin Invest Med 1994;17:B73. (Abst 433)

22. Ellner PD, Fink DJ, Neu HC, Parry MF. Epidemiologic factors affecting antimicrobial resistance of common bacterial isolates. J Clin Microbiol 1987;25:1668-74.

23. Oster SE, Chirurgi VA, Goldberg AA, Aiken S, McCabe. Ampicillin-resistant enterococcal species in an acute-care hospital. Antimicrob Agents Chemother 1990;34:1821-3.

24. Wiedemann B, Atkinson BA. Susceptibilities to antibiotics: Species incidence and trends. In: Lorian V, ed. Antibiotics in Laboratory Medicine, 3rd edn. Baltimore: Williams and Wilkins, 1991:962-1209.

25. Gordon S, Swenson JM, Hill BC, et al. Antimicrobial susceptibility patterns of common and unusual species of enterococci causing infections in the United States. J Clin Microbiol 1992;30:2373-8.

26. Currie BP, Gnass S, Levi MH. A hospital based stool culture survey to detect vancomycin resistant enterococcus (VRE) Utility and application. Infect Control Hosp Epidemiol 1995;16(Part 2, Suppl):P18. (Abst 15)

27. Cometta A, Calandra T, Bille J, Glauser MP. Escherichia coli resistant to fluoroquinolones in patients with cancer and neutropenia. N Engl J Med 1994;17:1240-1. (Lett)

28. Milatovic D, Braveny I. Development of resistance during antibiotic therapy. Eur J Clin Microbiol 1987;6:234-44. 


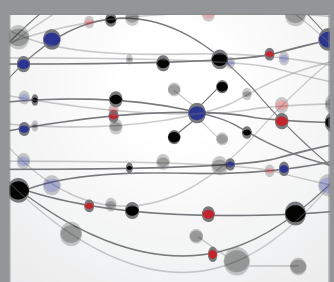

The Scientific World Journal
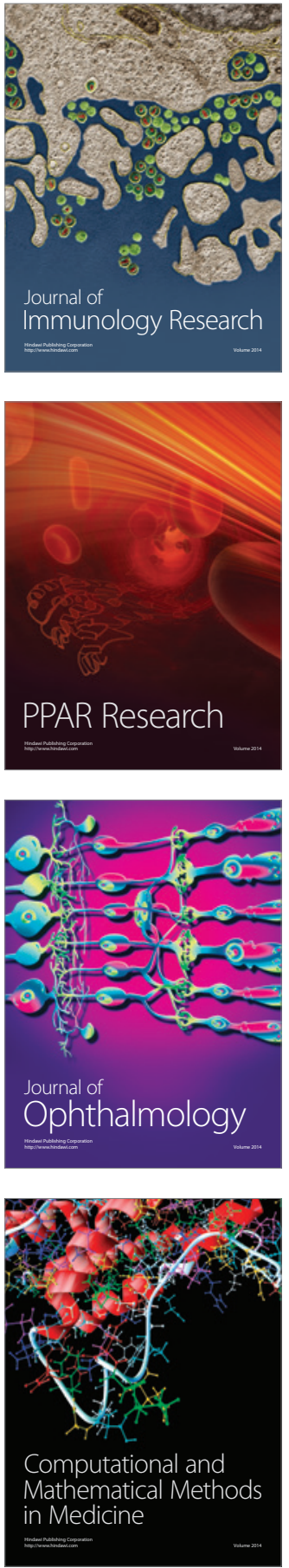

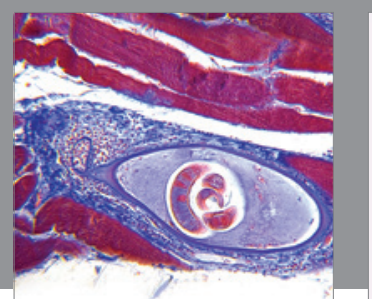

Gastroenterology Research and Practice

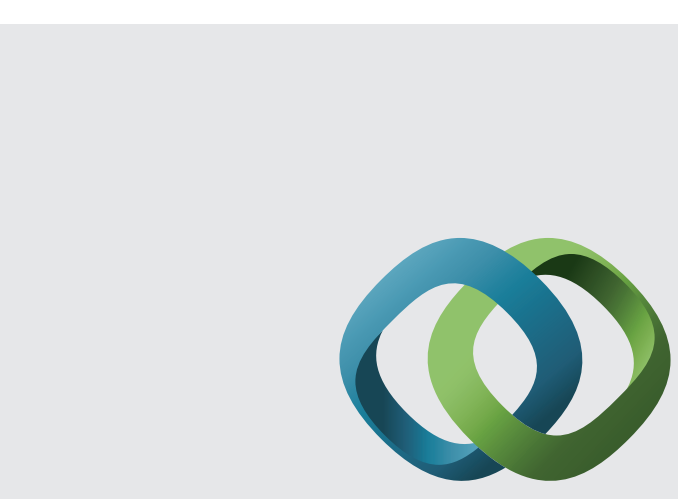

\section{Hindawi}

Submit your manuscripts at

http://www.hindawi.com
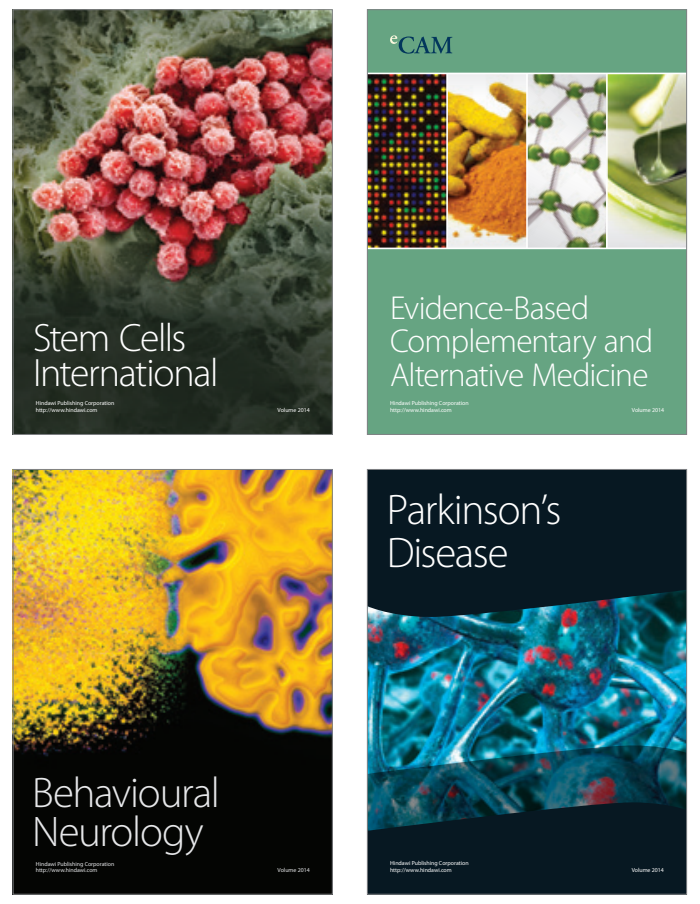
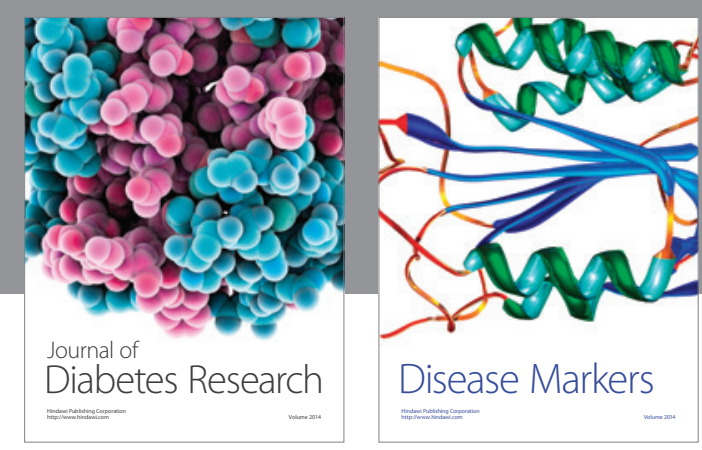

Disease Markers
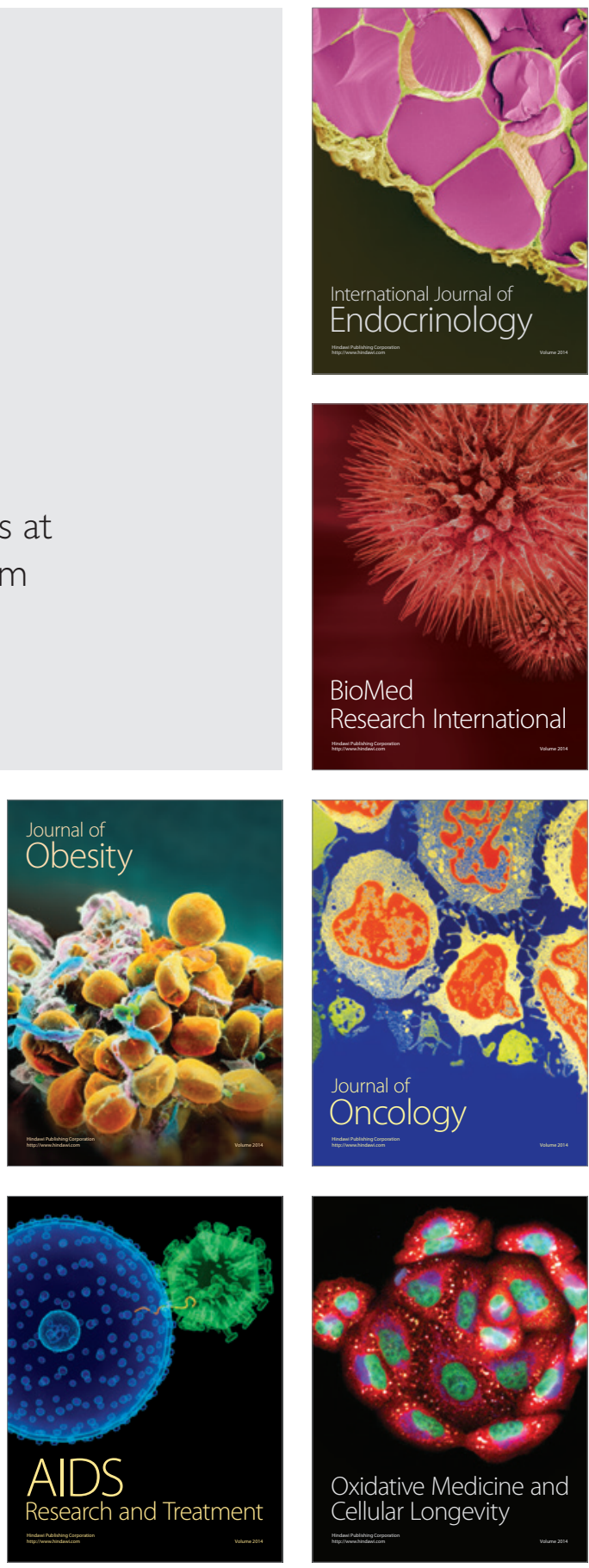